\title{
Kristi Salve
}

\section{ETNILISE AJALOO KAJASTUSI EESTI MUINASJUTUREPERTUAARIS (LÄÄNEMERE-BALTI SUHTED)}

\begin{abstract}
Teesid: Tavapäraselt on Soome, Eesti, Läti ja Leedu muinasjuturepertuaare vaadeldud kui "kahe vahel seisvaid", ühtaegu nii ida- kui läänepoolsete naabrite repertuaarist mõjustatuid. Ida all mõeldakse sealjuures üldiselt idaslaavlasi, eeskätt venelasi, lääne all esmajoones sakslasi ja rootslasi (või skandinaavlasi laiemalt). See pole vale, kuid kitsendav. Käesolevas artiklis on vaatluse all eeskätt sellised jututüübid, mis on tuntud läänemeresoome ja balti rahvastel, kuid puuduvad nende suurte naaberrahvaste repertuaaris. Osa neist juttudest on tuntud ka idapoolsetel soomeugrilastel või on neil paralleele koguni Siberi ja põlisameerika juttudega. Mõned läänemeresoomlastel ja lätlastel tuntud idapoolsete paralleelidega lood on jäänud läti repertuaari ilmselt substraadina läänemeresoome hõimukeelte kõnelejatest. Läänemeresoome-balti rühma muinasjutud sisaldavad tihti arhailisi usundilisi kujutelmi. Omapäraga paistab silma ka nende kunstiline struktuur, näiteks kasutatakse sellistes juttudes sageli laululisi vaheosi.
\end{abstract}

Märksõnad: arhailised hingekujutelmad, etnilised protsessid, läänemeresoome ja balti rahvad, muinasjutud, substraat, tüübikataloogid

Paljud muinasjututüübid ilmutavad hämmastavat elujõudu, püsides aastatuhandeid ja levides tervete mandrite ulatuses. Keelepiirid pole muinasjutule oluliseks takistuseks. Tervikuna on tegemist etniliselt labiilse žanriga, kuigi üksikjuhtudel võivad jutu levikut takistada mõne rahva mentaliteedile vastuvõetamatud sisuseigad või käsitluslaad. Neilgi puhkudel võivad abiks olla mitmesugused adaptsioonivõtted, mis võivad viia uute redaktsioonide tekkele.

Muinasjuttude pikaealisus ja labiilsus on loonud olukorra, mida võib veidi utreeritult sõnastada nii: iidsetest juttudest koosnev repertuaar ei tarvitse olla tervikuna vana. Nii koosneb teadaolev eesti rahvajutuvara põhiosas kogu Euroopas (ja laiemaltki) levinud jututüüpidest, mis on fikseeritud juba aastatuhandetetagustes muistse 
Kristi Salve

Lähis-Ida või India kirjalikes allikates. Heaks näiteks võib siin olla laia levikuga muinasjutt ATU 530 (Kuningatütar klaasmäel), ${ }^{1}$ mille üks, meil ja meie naaberrahvastel tuntutest õige tublisti erinev variant on papüürusele pandud juba Muinas-Egiptuses Uue riigi perioodil (Livšits 1979: 78-83). Kui kauges või lähedases minevikus on see paljudel Euroopa ja Aasia rahvastel registreeritud jutt jõudnud eestlaste sekka? Sama võib küsida paljude teiste meie ning lähemate sugulas- ja/või naaberrahvaste muinasjututüüpide kohta.

Eesti rahvajutte hakati arvestataval määral kirja panema alles 1870. aastaist alates, isegi 19. sajandi algupoolel kirjutati üles väga vähe jutte (üks suurem kollektsioon, Johann Heinrich Rosenplänteri (1782-1845) käsikiri Õpetatud Eesti Seltsi kogus on erandlik). Kuigi uuemate arvutuste järgi võib talletatud eesti imemuinasjuttude hulk küündida 6000 ligi (Järv 2005), ${ }^{2}$ on see rikkalik materjal ometi sedavõrd uus, et selle põhjal on äärmiselt raske, peaaegu võimatu anda usaldustäratavat vastust küsimusele, mida jutustati Eestis viissada, tuhat või kolm tuhat aastat tagasi.

Rahvalaulude osas toimus ühe kihistuse - regilaulu - väljavahetumine lõppriimilise lauluga suhteliselt hiljaaegu ja selle käiku on põhjalikult uuritud (Rüütel 1969). On ilmne, et traditsioonikandjad teadvustasid vormierinevusi regilaulu ja uuema laulu vahel, ning kui langetati valik viimase kasuks, muutus repertuaar üsna kiiresti, nii et võib isegi kõnelda murrangust. Muidugi olid ka regivärsilised laulud võinud sajandite ja aastatuhandete jooksul teemade, esitusviisi ning konkreetsete vormivõtete poolest muutuda, kuid need olid muutused ühe paradigma piires. Vaevalt need inimea jooksul hoomatavaks said.

Rahvajuturepertuaariski on muutused toimunud pidevalt. Ajapikku imbus sisse uusi süžeesid, jututüüpe, mis kandsid sageli kaasa uusi tegelaskujusid, hinnanguid, kunstilisi põhimõtteid jne. Samal ajal on kindlasti kogu aeg välja langenud - vaheetapiks võib-olla peri- 
feeriaisse taandumine - soosingu kaotanud jututüüpe, muidugi taas koos neile iseloomulike stiilivõtete, tegelaste ja muuga. Selle pikaajalise protsessi tulemus on meile teada: euroopaliku üldilmega repertuaar, mille omapärasemad jooned (mis on samas tihti vanapärasemad) ilmnevad alles üksikasjalikul vaatlusel.

Kõige hilisema perioodi muinasjutulaenude kohta on võidud saada otsesõnalisi andmeid veel esitajailt endilt ja need räägivad peamiselt vene või saksa päritolust. Ka niisuguste andmete puudumisel on hilisema repertuaari puhul sageli võimalik üsna suure kindlusega määrata, millised jutud on ida-, millised läänepoolset päritolu. Seda võimaldavad näiteks võõrapärased pärisnimed, olustikukujutus ja lähtekeelsetena edasiantud vormelid (Salve 1992: 86). Nii saksa kui vene (idaslaavi) jutuvara suhteliselt hea läbiuuritus ja (vähemalt trükis avaldatud) tekstide eneste kasutamise võimalus on suuresti abiks laenusuhete tuvastamisel.

\section{"Põhjadimensioon"}

Hoopis keerukam on võrrelda omavahel eestlaste (läänemeresoomlaste) ja teiste soome-ugri (või laiemalt uurali) rahvaste muinasjutte, sest vajalikud eeltööd kogumise, aga ka arhiivide korraldamise, publitseerimise ja uurimise kujul pole kaugeltki piisavad. Selle materjali põhjal, mida on võimalik kasutada, on siiski silma torganud üks põhimõttelist laadi asjaolu: need jututüübid ja motiivid, mis on teadaolevalt tuntud nii läänemeresoomlastel kui ka põhja- ja idapoolsetel sugulasrahvastel, evivad enamalt jaolt vasteid ka muudesse keelkondadesse kuuluvatel Siberi rahvastel ( $\mathrm{mh}$ paleoasiaatidel), vahel aga ulatuvad nad isegi Põhja-Ameerika põlisrahvasteni või veelgi kaugemale. ${ }^{3}$ Nõnda siis näib kergemini eralduvat pigem mingi laiem muistne subarktiline kui spetsiifiliselt soomeugriline (või uurali) jutukihistus. Seetõttu jääbki suuresti lahtiseks küsimus, kas läänemeresoomlased on niisugused jutud oma praegustele asualadele kaasa 
Kristi Salve

toonud või omandanud need alles siin tundmatut päritolu algrahvastikult, kellelt on arvatud pärinevat substraatsõnu läänemeresoome keeltes (Ariste 1981: 21-23).

Üpris tugevasti on arktiline repertuaar esindatud laplastel. Süvenemata selle rahva etnogeneesi probleemidesse ei vanemate ega hiljuti ilmunud teooriate põhjal, osutame Erkki Itkoneni seisukohale, mille järgi laplased on säilitanud oma folklooris palju algsoomeugrilist (Itkonen 1976). Kuna läänemeresoomlastest tunnevad selliseid jutte eeskätt põhjapoolsed, võib eeldada - vähemalt mõnel puhul laplaste vahendust või lapi substraati. Kõige ilmsem on see näiteks AT 975* (Vahetatud lapsed) puhul, mis on lapi traditsioonis üks populaarsematest lugudest ja mille vasteid võib leida paljudelt rahvastelt mansidest kuni Aasia eskimoteni ja nanaideni (Itkonen 1960). Soomlased tunnevad sellest jutust ühtainust varianti (Rausmaa 1982: 323-324, 370) ning selles esinevad tegelasnimedki osutavad, et soomekeelsel kujul ei ole ta saanud kuigi kaua käibida.

Kaunis tõenäoliselt võib laplaste vahendusega olla tegu AA*967 (Metsaasukas ja röövlid) puhul. See jutt on tuntud laplastel, karjalastel, soomlastel, vepslastel, Karjala venelastel ja Siberi rahvastel ning näib olevat säilitanud algseid jooni just leviku perifeerias - ühelt poolt kettidel, teiselt poolt laplastel ja soomlastel. Seose tõttu bõliinaga Rahta Ragnozerski on AA* 967 saanud vene folkloristide huvi osaliseks. Kirill Tšistov, tundmata küll muid kui vene, karjala ja lapi teisendeid, jõudis seisukohale, et algseks oli lapi (või ka vessi) pärimus, kellelt see läks läänemeresoome traditsiooni, läänemeresoomlastelt aga võtsid selle üle venelased (Tšistov 1958: 377). Viimases pole põhjust kahelda. Mis puutub jutu ajaloosse enne Vene ekspansiooni algust, jääb mitu võimalust, millest olulisimad on a) läänemeresoomlased said jutu laplastelt, b) läänemeresoomlaste ja laplaste iseseisev laen algasukatelt - ning lõpuks on võimalik ka, et c) jutt pärineb soomeugrilisest kihistusest ning selle on laplaste ja lääne- 
meresoomlaste eelkäijad praegustele asualadele kaasa toonud. Viimasel juhul on eestlased jutu lihtsalt unustanud (Salve 1995).

Siiski on ka eestlased säilitanud ürgseid jutte, vahel koguni läänemeresoome rahvastest ainukestena, nagu on juhtunud tekkelooga tüübist AaUs 7 (Vaeslaps kuul). Niisugune kuu tumedate laikude olemust seletav tekkelugu on peale kaugemate soomeugrilaste, nimelt udmurtide (Vereštšagin 1995) ja komide (Ariste 2005: 108-111) tuntud mitmel Siberi rahval (Annist 1966: 240-241). Kindlasti väärib tähelepanu tõik, et Eestis näib kõnesoleva jutu levikuala piirduvat maa lõunapoolse osaga. Väljastpoolt lõunaeestilist keeleala on fikseeritud ainult üksikud tekstid, mis pealegi kutsuvad esile nii- või teistsuguseid kahtlusi (kirjanduse mõju vm), samas kui Kagu-Eestis oli see kaunis jutt elav veel 20. sajandi viimastel kümnenditel.

Tervikjuttudest palju rohkem kohtab vanimasse ajaloolisse kihistusse kuuluvaid motiive, detaile, tegelasi. Nende kindlaksmääramine nõuab aga paljude repertuaaride tundmist, paljude jututüüpide monograafilist läbiuuritust. Näiteks selgus Uku Masingu uurimusest ATU 830 A (Tänamatu põdrapüüdja) kohta, et mõnes eesti variandis esinev etioloogiline lõpp, mille kohaselt põdra tagajalgades võib tänini näha (teatud liikuva luuna) nuga, mida oli kasutatud poolelijäänud nülgimise juures, on tuntud ka laplaste ja teiste põhjarahvaste juttudes (Masing 1990).

Arvesse tuleb ka võimalus, et muistsesse kihistusse kuulunud juttude süžeed on hiljem värsistatud ja jõudnud meieni lauludena. Väga laialt levinud Põhja-Euraasia müüdi obiugri redaktsiooni värsistatud vasteks on näiteks soome-karjala runo Hiie hirve küttimisest (Hiiden hirven hiihdäntä). Mitmete läänemeresoome rahvaste, sealhulgas eestlaste seas populaarsete mütoloogiliste laulude Loomine ja Suur tamm rohketele lähematele ja kaugematele müüdivastetele on korduvalt osutatud. Sellekohased peamiselt Soome teadlaste uurimistulemused on kokku võtnud Matti Kuusi (1963: 31-80). Viimaste süžeede 
Kristi Salve

puhul on lisaks juurtele paleoarktiliste rahvaste muistses kultuuripärandis täheldatavad impulsid Lähis-Ida vanadest kõrgkultuuridest. Sellesuunalistele seostele on osutanud ka eesti uurijad (Masing 1977, 1985).

Oskar Loorits on näidanud, et Vana-Idamaade kõrval on meie jaoks olnud tähtsaks kultuurimõjude allikaks hilisemal perioodil Bütsants, kõige viimase kihistuse idapoolsete juttude hulgas moodustavad aga venelastelt laenatud (Loorits 1934). Ka on O. Loorits käsitlenud diferentseeritult läänepoolse päritoluga jutte, juhtides hilisemal ajal sakslastelt saadu kõrval tähelepanu ka germaani laenude varasemale kihistusele. O. Looritsa antud ülevaate kõrval on hilisemates ülevaateteostes (Viidalepp 1959; 1980) eesti juturepertuaari seoseid nähtud palju vaesemana. On piirdutud ühelt poolt Lääne-, teiselt poolt Ida-Euroopale omaste tüüpide esinemise konstateerimisega, millest esimesed on saadud sakslaste, osalt ka rootslaste, teised aga venelaste vahendusel (Viidalepp 1980: 230). Vene mõju olulisust on mitmel puhul rõhutatud (Viidalepp 1980: 230, 244, 249250), mille puhul mängisid kindlasti kaasa ka nõukoguliku ideoloogia postulaadid. Üksikute muinasjuttude puhul on osutatud siiski ka nende tuntusele balti rahvaste repertuaaris, näiteks ATU 425 M (Ussi naine) erilisele populaarsusele leedulastel (Viidalepp 1980: 244).

\section{Läänemeresoome-balti kihistus}

Õieti äratab imestust, et avara silmaringiga O. Loorits ei pööranud tähelepanu eesti (ja läänemeresoome) ning balti rahvaste muinasjuttude seostele. Põhjusena tuleb muidugi arvesse see, et kuigi arheoloogia ja keeleteadus olid kindlaks teinud põliste kultuurisidemete olemasolu ja kuigi ka Balti riikide rahvaluulearhiivid arendasid tihedat koostööd, polnud kaua aega piisavalt eeldusi juturepertuaaride süstemaatiliseks võrdlemiseks. Muinasjuttude tüübikataloog oli pikka aega olemas ainult eesti materjali kohta (Aarne 1918) ja seegi 
kajastab üksnes Jakob Hurda kogus leiduvaid jutte. 1930. aastate lõpul muutusid võrdlusvõimalused palju soodsamaks seoses leedu muinasjutukataloogi ilmumisega (Balys 1936).

Eesti Rahvaluule Arhiivi muinasjutukartoteegi põhjal on hästi jälgitav, kuidas hulk varasemate kataloogide (sealhulgas rahvusvahelise Antti Aarne ja Stith Thompsoni kataloogi esimese, 1928. aasta väljaande) põhjal määramata jäänud lugusid sobitus hästi Jonas Balyse leedu materjali alusel kirjeldatud tüüpidesse. Läti muinasjutud said rahvusvahelisele uurimisele kättesaadavaks veel palju hiljem. Aarne-Thompsoni teises, täiendatud väljaandes (1961, kordustrükk 1973) on esitatud ainult läti loomamuinasjutud 1940. aastal ilmunud kataloogi (Medne 1940) põhjal. Kõiki liike hõlmav kataloog ilmus lätlastel alles 1977. aastal (Arājs \& Medne 1977), kuid hõlmates kogu arhiivimaterjali, ületas see aastakümnetetaguse A. Aarne koostatud kataloogi ja repertuaaride läheduse tõttu pakkus tuge ka eesti juttude tüpologiseerimisel. Praegu annab ammendava ülevaate eesti repertuaari ühest osast - loomamuinasjuttudest - Pille Kippari koostatud kataloog (Kippar 1986), loodud on imemuinasjuttude andmebaas jne. Nii on viimasel ajal balti ja läänemeresoome rahvaste ühise jutuvara selgitamine üha hõlpsamaks saanud.

1980. aastatel ongi eesti folkloristid meie muinasjuttude tüübikoosseisu iseloomustades hakanud esile tõstma balti-läänemeresoomelise levikuga jututüüpe (Masing 1984; Kippar 1984, 1986; Salve 1984). Esimene monograafiline käsitlus ühe sellesse rühma kuuluva loomamuinasjutu kohta ilmus siiski juba mõni aasta varem (Kippar 1975).

Uku Masing on nimetanud selliseid läänemeresoome ja balti rahvastele ühiseid muinasjutte nagu AT 65* (Rebane praeb sitikat), ATU 130 A (Härja maja), ATU 150 A* (Konna õpetused), AT 403 C (Rõugutaja tütar), AT 530 B (Varastatud mõrsjad), ATU 572* (Kuningatütre meelitamine) jt, "Lõuna-Eesti substraatjuttudeks" (Masing 1984: 
Kristi Salve

482-483). Mõnel U. Masingu loendis nimetatud jutul on olemas ka vene (idaslaavi) variante. Paari niisugust vaatleme allpool veidi lähemalt. Igal juhul on teistel slaavi, germaani jm Euroopa rahvastel tundmata, kuid balti ja läänemeresoome rahvastel populaarse ja venelastel kohati tuntud jutu puhul tõenäolisem, et jutt on venelastel substraatne, eriti kui ta levik haarab endisi balti või läänemeresoome alasid.

Et P. Kippar on silmas pidanud ka laiemalt levinud juttude omapäraseid läänemeresoome-balti redaktsioone (sellist redaktsiooni kujutab endast ka tema poolt monograafiliselt uuritud ATU 150 A Konna ópetused), võib arvata, et P. Kippari oletatud kolmest ühisrepertuaari kujunemise võimalusest esimene käib just nende eriredaktsioonide kohta. See võimalus on P. Kippari järgi tingitud asjaolust, et balti ja läänemeresoome rahvad on vastu võtnud ühtmoodi mõjutusi nii ida kui ka lääne poolt (Kippar 1975). Pole siiski usutav, et ühtlane, ilmekas eriredaktsioon võiks kujuneda mitme rahva seas iseseisvalt ainult sel alusel, et kõik rahvad on puutunud kokku ühesuguste ida- ja läänepoolsete redaktsioonidega. Pirkko-Liisa Rausmaa, kes on mõne muinasjututüübi najal lähemalt uurinud ida- ja läänepoolsete redaktsioonide kohtumist Soomes, on võinud küll nimetatuist emba-kumba esindavate soome variantide kõrval täheldada selliseidki, mis sisaldavad nii ühele kui ka teisele omaseid motiive (Rausmaa 1973: 135), kuid need on suhteliselt vähesed hajali asetsevad variandid, mis ei moodusta selgeid eriredaktsioone.

Läänemeresoome-balti erirepertuaari kujunemise teisteks võimalusteks on P. Kippari järgi olnud tekkimine eri hõimude segaasustuse tingimustes ja lõpuks vastastikune laenamine hilisema suhtlemise käigus. Substraadi võimalust P. Kippar otsesõnu esile ei too, kuigi tema monograafiast jututüübi ATU 243* (Varese naisevõtt) kohta näib järelduvat, et see on lätlastel läänemeresoome substraat: läti tekstid pärinevad nimelt endistelt läänemeresoome aladelt. P. Kippar ise on sel puhul siiski arvestanud laenamist (Kippar 1985: 94). 
Üsna kindlasti on balti ja läänemeresoome rahvastele omaste muinasjuttude hulgas erineva päritolu ja levikuga jututüüpe, kusjuures sageli on raske otsustada, kuidas on lugu just ühe või teise konkreetse tüübiga. Mõned üldisemad orientiirid võib ometi fikseerida. Üks olulisemaid on käsitletavate juttude levikuala kogumisperioodil (19.20. sajand). Selle põhjal võib eristada järgmisi rühmi: a) kõigil (või suuremal osal) läänemeresoome rahvastel, lätlastel ja leedulastel tuntud muinasjutud, mis vahel võivad olla esindatud ka kaugematel soome-ugri rahvastel ja/või venelastel; b) sporaadilise levikuga jutud, mille hulgast väärivad erilist tähelepanu mõned arhailiste tunnustega, ainult Leedus ja Eestis tuntud lood; c) eestlastel ja põhjapoolsetel läänemeresoomlastel (soomlased, karjalased) levinud muinasjutud, mida balti rahvastest tunnevad ainult lätlased; d) eestlastele ja lätlastele ühised jutud, mida ei tunne teised rahvad.

Suurima tõenäosusega võib läänemeresoome substraati eeldada c-rühma muinasjuttude puhul. Kaugemate soome-ugri või Siberi rahvaste paralleele omavaid a- ja b-rühma jutte võib samuti pidada substraatseteks või on nad balti rahvaste repertuaaris väga vana laen meist ida pool asunud soomeugrilastelt. Juttude puhul, millel puuduvad paralleelid väljaspool läänemeresoome ja balti rahvaste nüüdseid territooriume, on väga raske otsustada, millises etnilises keskkonnas nad on kunagi tekkinud. Põhjendatult võib eeldada ainult selliste juttude kõrget iga vähemalt sel juhul, kui nad on esindatud variantidega põhjapoolsematest läänemeresoomlastest leedulasteni.

\section{Eesti-läti jutud: substraat ja hilislaenud}

Suhteliselt kõige vähem problemaatiline on d-rühma juttude päritolu. Seejuures pole üsna tüübirikas eesti-läti erirepertuaar ise sugugi homogeenne. Näiteks tundub otstarbekas vaatlusest hoopis välja jätta rida esimesena Alma Medne poolt läti materjali põhjal kirjeldatud (Medne 1940) pajatusesarnaseid loomajutte, mis on sisse võe- 
Kristi Salve

tud ka Aarne-Thompsoni kataloogi uude väljaandesse ja millele paari aastakümne taguses eesti loomamuinasjuttude kataloogis (Kippar 1986) võidi enamasti lisaks tuua eesti variandid. Tundub väga tõenäoline, et neid jutte, mida peeti tõsielusündmusi edastavaiks, on jutustatud teistegi rahvaste seas, ainult et väljaannete avaldajad ja kataloogide koostajad pole pidanud neid muinasjuttudeks. Uus idaslaavi kataloog (SUS), mis põhineb paraku ainult trükistel, osutabki mõnel juhul, et neid jutte, nt ATU 166 A* (Hunt pistab saba lauta) tunnevad ka idaslaavlased. Läänemeresoome-balti suhete uurimise seisukohalt pole sedalaadi jutud niisiis kuigi tõestusjõulised.

Vaatleme järgnevalt mõnd sellist eesti-läti ühist muinasjuttu, mida muudel rahvastel ilmselt tõesti pole ja mille olemasolu mõlemal nimetatud rahval annab tunnistust nende nii- või teistsugustest ajaloolistest sidemetest.

Üsna kindlasti võib pidada läänemeresoome (lõunaeesti) pärandiks lätlastel kahe variandiga esindatud AT 37* (Rebane hanekarjas). See muinasjutt on olnud eriliselt soositud setude ja lutsi maarahva hulgas. Etnilisi piire on ta nähtavasti kindlalt hoidnud, st pole üle nende liikunud. Kaks registreeritud läti varianti põlvnevad Ludza ümbrusest, seega väga tõenäoliselt lutsi maarahva assimileerunud järeltulijailt. Võib-olla on muinasjutt olnud kunagi läänemeresoomelises Latgales laiemaltki levinud, kuid kadunud mujalt varem.

Eestlaste ja lätlaste ühiste loomajuttude hulka kuulub veel näiteks ATU 122 L* (Härg ja pime hunt). See on Eestis esindatud ühe Tarvastu, ühe Vastseliina ja rea setu teisenditega (nende täpset arvu on raske nimetada, sest osa neist on tõenäoliselt dubletid). Kahest läti teisendist on üks Bauska, teine Jelgava ümbrusest, st maa lõunaosast. Võimalik, et jutt on taandunud kunagise laiema levikuala perifeeriasse. Selle muinasjututüübi suhtes on raske kindlalt väita, kas ta on algselt välja kujunenud läänemeresoome või balti keelekeskkonnas, päriselt välistada ei saa ühte ega teist. 
Kolmas loomajutt, ATU 156 B (Naine ussi katsikuliseks), on lätlastel esindatud rea variantidega Riia, Rezekne, Daugavpilsi ja Talsi ümbrusest, samal ajal kui Eestist on teada ainult üks setu tekst. Variantide hulga ja leviku järgi võib loo tekkekohaks pidada praegust Läti territooriumi. Millises etnilises keskkonnas jutt välja kujunes, on raskem öelda. Läänemeresoomlaste osa ei saa lõplikult välistada, sest mõnedki läti teisendid pärinevad kunagistelt läänemeresoome aladelt. Jutu sõnum (loomadesse tuleb suhtuda nagu omasugustesse, nad mõistavad seda hinnata) sobib hästi põhjapoolsetele küti- ja kalurikultuuridele omaste hoiakutega.

Eespool juba kõne all olnud muinasjututüüp ATU 830 A (Tänamatu põdrapüüdja) on samuti levinud teadaolevalt ainult Eestis ja Lätis, kusjuures Eestis on see tunduvalt populaarsem (22 varianti Läti viie vastu). Väärib märkimist, et Eesti variandid on jaotunud üle kogu maa, mitmeid üleskirjutisi on isegi folkloorivaesest läänepoolsest Eestist. Vähesed Läti variandid paiknevad samuti hajali üle maa. Suures osas jutu teisenditest esineb etioloogiline lõpp, mille kohaselt heledamad kohad põdra kõhul ja jalgadel on alustatud (kuid looma elustamise tõttu pooleli jäänud) nülgimistöö jäljed. Märksa huvipakkuvam on vähestes eesti teisendites esinev etioloogia - teatud luuna põdra tagajalas on nähtav ja kombatav nülgimisnuga. Selle ja tapetud metslooma taaselustumise kujutelma enda rohked paralleelid arktilistel ja subarktilistel rahvastel lubavad pidada ATU $830 \mathrm{~A}-\mathrm{d}$ soomeugriliseks pärandiks eesti repertuaaris. Lätlastel on jutt tõenäoliselt substraatne.

ATU 843* (Laisk kuduja), mis nagu ATU 830 A-gi kuulub legendilaadsete muinasjuttude hulka, on olnud üsna laia levikuga nii Eestis kui ka Lätis. Selle moraliseeriva jutu puhul, kus ei esine ühtegi üleloomulikku motiivi, võiks oletada isegi mõlemale rahvale ühist, tundmatuks jäänud kirjanduslikku allikat. Niisuguses legendilaadsete muinasjuttude puhul sageli arvesse tulevas võimaluses sunnib kaht- 
Kristi Salve

lema ja siiski folkloorset päritolu eeldama asjaolu, et leedulastelt ja setudelt (viimastel on tuntud ka normaalne ATU 843*) on kirja pandud ATU 843* eriredaktsioonina vaadeldavaid jutte, milles oma töö lõpuleviimiseks saab julgust põldu raadav talumees.

\section{Läänemeresoome-läti jutud}

C-rühma (kahel või rohkemal läänemeresoome rahval ja lätlastel tuntud) juttudest on ühte, nimelt ATU 243* (Varese naisevõtt), põhjalikult uurinud P. Kippar (Kippar 1985). Eestis on ATU 243* olnud üks tuntumaid loomajutte. Läänemeresoomlastest on seda tundnud veel soomlased, karjalased ja liivlased. Lätlastelt kirja pandud variandid pärinevad Vidzemest ja Latgalest - aladelt, kus minevikus oli läänemeresoomeline asustus. P. Kippari hinnangut mööda on läti variandid laen eestlastelt-liivlastelt (Kippar 1985: 94). Tundub siiski, et laenu asemel võib selle jutu puhul kõnelda substraadist.

Nagu eelmine jutt, nii on ka AT 240 (Meika munavahetus) seotud loodushäälendiga. Ühtlasi on nii AT 240 kui ka AT 240* (Munavahetus võidujooksuga) etioloogilised, seletades, miks metstuvi muneb ainult kaks muna, kana aga palju mune. AT 240 on levinud eestlastel, soomlastel, soomerootslastel, rootslastel, AT 240* eestlastel ja lätlastel. Rootsi uurija Waldemar Liungman on AT 240 kohta arvanud, et see on tekkinud Eestis (Liungman 1961: 32). Võib-olla oleks õigem pidada seda juttu üldisemalt läänemeresoomeliseks, sest tekkekoha konkretiseerimine Eestisse pole kuidagi tõestatav. Jutu tuntus Soomes ja eriti Rootsis laseb pigem arvata, et ta on põliselt omane ka põhjapoolsematel läänemeresoome aladel. AT 240 tugevat traditsiooni Eestis ei saa muidugi eitada, samuti on Eestis hästi tuntud olnud sugulaslik AT 240*. Nende jututüüpide levikut võrreldes torkavad silma erinevused: viimane tüüp pole tuntud üle maa, vaid põhiliselt Lõuna- ja Edela-Eestis. Läti teisendeid on ainult kaks, neist üks kirja pandud Riia, teine Võnnu (Cēsise) ümbrusest. Ilmselt ku- 
junes AT 240* kunagi välja AT 240 alusel läänemeresoomlaste asuala lõunaosas, st tänapäeva Lõuna-Eestis ja Põhja-Lätis. Paralleelselt tuleb siiski arvesse võimalus, et Munavahetus võidujooksuga on pärit hilisemast ajast, mil etnilised piirid olid juba tänapäevastele lähedased. Sel juhul oleksid kaks ainukest läti varianti seletatavad üksikute jutustajate või inimrühmade hilisema ümberasumise ja -asustamisega. Substraadivõimalus on siiski tõenäolisem.

Läänemeresoome-läti ühisjuttude hulka näis kuuluvat ka legendilaadne AT 832 (Ahne kalamees), mis on esindatud soomlastel, eestlastel, liivlastel ja lätlastel. Kõige rohkem teisendeid on kirja pandud lätlastelt, seejuures igast maa osast. Siiski ei kuulu AT 832 lätlastelgi 12 variandiga nimetamisväärselt populaarsete lugude hulka, eestlastel on ta veel haruldasem ning soomlastelt ja liivlastelt on seda üles kirjutatud ainult üks teisend. Ahne kalamehe lugu näitab, kui palju sõltub juttude publitseerimisest ja eriti kataloogide koostamisest. Uus rahvusvaheline kataloog (ATU) lisab leedu, poola, saksa ja slovaki teisendid, aga sellest ilmneb $\mathrm{ka}$ - mis eriti oluline -, et juttu on tuntud Iraanis ja Jaapanis. (Juudi ja Lõuna-Aafrika tekstide päritolu ja kuuluvust pole üksnes kataloogi põhjal võimalik hinnata.) Tundub tõenäoline, et jutt on Läänemere-äärsetes maades levinud kirjanduse vahendusel. Aluseks võib sel juhul olla nii rahvakeelne vagajuttude väljaanne kui ka jutlustajatele kasutamiseks mõeldud eksemplite kogu.

\section{Läänemeresoome põhjapiirist leedulasteni}

Eesti-läti ja läänemeresoome-läti juttude hulk on muidugi suurem ega piirdu eespool vaadeldutega. Tundub siiski, et läänemeresoomebalti suhete uurimiseks on kaalukamad need jututüübid, mille levik haarab kogu või vähemalt suurema osa läänemeresoome ja balti rahvastega asustatud territooriumist põhjast lõunani, kusjuures oluline on esindatus leedulastel. Võib arvata, et sel muinasjuttude rühmal, 
Kristi Salve

mida eespool tähistasime a-ga, on ajalooliselt palju ühist b-rühmaga, st leedulastel ja mõnedel läänemeresoomlastel (sageli ainult eestlastel) tuntud juttudega. Mõlema rühma jutud on oma loomult õieti väga lähedased, eraldamise aluseks ongi ainult levik, mis esimesel puhul on läänemeresoome-balti alal laiem ja pidev. Mõnel juhul on õigustatud vaadelda a-rühma piires niisuguseidki muinasjutte, millel on otseseid või kaudseid paralleele kaugemate soome-ugri rahvaste, aga ka vene repertuaaris. Täpselt samuti võib b-rühma jutte pidada kunagi minevikus sama laialt levinuiks, kuid hiljem taandunuiks oma praegusele levikualale - seega reliktseiks.

Laiema levikuga läänemeresoome-balti muinasjuttudele on iseloomulik see, et nad esinevad väljakujunenud redaktsioonidena. Redaktsioonide levikupiirid langevad kokku praeguste või (sagedamini) endiste etniliste piiridega. Redaktsioonilisus ilmneb konkreetsete motiivide, kompositsiooni ja käsitluslaadi tasandil. Siin võib osutada analoogilistele ilmingutele runolauludes. Mitmetel läänemeresoome rahvastel esinevatest lauludest on osa võinud keelelise läheduse ja ühise värsiehituse tõttu levida ühelt rahvalt teisele laenudena. Niisuguseid laule eristab kõige vanemast ühispärandist see, et viimasesse kuuluvad runolaulud on pikaaegse eriarengu käigus jagunenud omavahel märgatavalt erinevaisse redaktsioonidesse (Kuusi 1963: 183). Jättes kõrvale lauluvormi erinevusest paratamatult johtuvad lahknemised, on näiteks mordva-balti-läänemeresoomeline $\mathrm{Hu}$ mal (Humalan ja ohran kerskaus) eri rahvastel sisult ja kompositsioonilt üsna omapalgeline. Muutlik on ka käsitluslaad, ulatudes murelikust hoiatusest humala salakavaluse eest kuni joomalaulu minnalaskva uljuseni (Kuusi 1963: 140-141).

Läänemeresoome-balti muinasjuttude rahvuslike redaktsioonide vahel võib samuti täheldada stiili ja ainekäsitluse erinevusi, mis mõnel puhul viivad selleni, et eri redaktsioonid liigituvad erinevatesse jutužanridesse. Nii on leedulaste, lätlaste ja vepslaste ATU 1559 A* (Pet- 
lik kihlvedu: inimese või looma nälg) variandid tüüpiliste naljandi tunnustega. Tegelasteks (kihlveo sõlmijaiks) on inimesed, pinget loob sotsiaalselt kõrgemal seisva ja ühtlasi rumalama härra ületrumpamine talupoja (või karjase) poolt. Setus on sama sisumotiivi (inimest pole loomast erinevalt võimalik lõplikult täis sööta) rakendatud hoopis teistviisi. Tegevus toimub müüditasandil, kihlveo sõlmijaiks on Jumal ja Kurat. Inimese kommet süüa ka täis kõhuga käsitletakse patuna, mille tõttu Kurat saavutab võidu.

Kui ATU 1559 A* levik on sporaadiline, siis ATU 572* (Haukuv koerapea, iseraiuv kirves jne) on tuntud pideval alal Ida-Soomest ja Karjalast Leeduni. Kuigi veel Aarne-Thompsoni tüübikataloogi 1961. aasta väljaanne esitab selle tüübinumbri all ainult eesti variandid (vt ka Viidalepp \& Mälk \& Sarv 1967: 507, sub 87), selgus 1970. aastate uute kataloogide ja teaduslike väljaannete (Arājs \& Medne 1977; Rausmaa 1972; Kerbelytė 1982) põhjal eespool osutatud levipiirkond. ATU andmeil on juttu tuntud ka Kreekas ja Gruusias. Sealseid tekste tundmata on targem nad vaatlusest välja jätta, mööndes siiski, et ATU 572* võib olla tõend vanadest kultuurisuhetest Bütsantsiga. Kõige populaarsem (mitukümmend teisendit) on jutt olnud Eestis, soome ja karjala variante on kokku 22 ja leedu omi 17. Läti jääb teistest oma üheksa teisendiga maha. Ühe läti teisendi päritolukoht on teadmata, kaks on pärit Bauska ümbrusest (st Leedu piiri lähedalt) ning ülejäänud maa kaguosast - lõunapoolsest Latgalest. Leedus on muinasjuttu fikseeritud Aukštaitijast. Eesti variante on silmapaistvalt rohkesti Setumaalt. AT 572* tugevat põhja sealses traditsioonis näitab ka asjaolu, et sama süžee on setude hulgas käibinud paralleelselt lauluna, millele Jakob Hurt on andnud tüübinimetuseks Kuningatütre meelitamine (Hurt 1904: A 51). Jutuna on ATU 572* olnud Setumaal mõeldud nähtavasti eeskätt lastele esitamiseks, sest selle sõnastus on hoolega välja töötatud, vormelirikas, esineb ka laululisi vaheosi. Muud eesti variandid (mida on ar- 
Kristi Salve

vukamalt üldse muinasjuturikkalt Võrumaalt, aga ka Virumaalt ja vähem mitmelt poolt mujalt) ei ole küll nii viimistletud stiiliga, kuid näivad oma käsitluslaadi poolest sobivat mitmekesisele kuulajaskonnale, muude hulgas kindlasti lastelegi. Soomes on käsitluslaad P.L. Rausmaa järgi tublisti erinev. Sageli on ATU 572* seal esitatud valetamisjutu stiilis, tihti esineb üpris jõhkraid detaile (Rausmaa 1972: 428). Nende asjaolude põhjal võib arvata, et seal on jutt kuulunud eeskätt meeste repertuaari. Siingi võib näha pika iseseisva arengu tagajärjel kujunenud käsitluslaadi ja funktsiooni põhjal eristatavaid redaktsioone. See on aga omakorda kinnituseks jutu kõrgele eale.

Pideval, Karjalast Leeduni ulatuval alal tuntud muinasjututüübiks on ka AT 530 B* (Varastatud mõrsjad). Algusosas on sellel jutul palju ühist laialt levinud ning väga populaarse ATU 530-ga (Kuningatütar klaasmäel). Erinevused algavad juba jutu keskmises osas. Selle asemel, et kolmel korral kuningatütreni jõudmist üritada, külastab kolmas vend iga kord erinevat pulmapidu ja röövib sealt mõrsjad. ATU 530 on kindlasti avaldanud olulist mõju AT 530 B* kujunemisele. Võimalik, et AT $530 \mathrm{~B}^{*}$ teiseks komponendiks on olnud mingi naiseröövimisest kõnelev, varem ajaloolisena käsitatud jutt, mis hiljem, kui ta oma esialgse tähenduse oli minetanud, liideti muinasjutumotiividega. Igatahes pole AT $530 \mathrm{~B}^{*}$ saavutanud oma eeskujujutuga mingilgi määral võrreldavat populaarsust. Karjalast on teada ainult üks teisend. Niisamuti on lugu Lätis, kusjuures ainus, Tukumsi lähikonnast kirja pandud tekst on kaotanud tüübile iseloomuliku motiivi - pruutide röövimise pulmapidudelt. Tugevam traditsioon on tüübil Leedus ja Eestis. Leedus on AT $530 \mathrm{~B}^{*}$ tuntud peamiselt maa kaguosas (Kerbelytè 1982: 429, sub 62). Eesti variandid pärinevad praeguste andmete kohaselt kõik kas setudelt või siis lutsi maarahvalt. Viimane seik on tähelepandav, sest läti variante Latgalest ju pole. 


\section{Lähivaade üheksa velje sõsarale}

Laiema levikuga jututüüpidest väärib lähemat vaatlust AT $451 \mathrm{~A}$ (Üheksa velje sõsar; kasutusel on olnud mitmeid tüübinimetusi, vt Aarne-Thompson 1961, 1973; Arājs \& Medne 1977; Rausmaa 1967). Sellele leidub lähedasi paralleele (mida võib vaadelda isegi antud tüübi redaktsiooniliste variantidena) mordvalastel, maridel ja venelastel, kuid põhiline levikuala on siiski läänemeresoome-balti areaal. Tüüpi kirjeldas esimesena J. Balys leedu materjali põhjal (Balys 1936) ja selle alusel on jututüüp esitatud ka Aarne-Thompsoni rahvusvahelise kataloogi teises, täiendatud väljaandes (Aarne-Thompson 1961, 1973). Soome ja Eesti materjali ei kajasta Aarne-Thompsoni kataloog sellepärast, et vastavad Antti Aarne koostatud rahvuslikud kataloogid (Aarne 1911; 1918) esitasid vaadeldava tüübi variandid 451 all, sest tüübi määramisel loeti otsustavaks mõlemale jutule ühiselt omased algusmotiivid. Kārlis Arājs ja Alma Medne on AT 451 A andnud J. Balyse eeskujul eraldi tüübina.

Hilisemal ajalgi pole olnud üksmeelt Üheksa velje sõsara suhtes. Teenekas Soome muinasjutu-uurija P.-L. Rausmaa on oma monograafias käsitlenud seda AT 533 (Kõnelev hobusepea) erikujuna (Rausmaa 1967). Ilmselt tema põhjendusi arvestades on Unelma Konkka oma tekstipublikatsioonis niimoodi määranud ka Kesk-Karjala variandid (Konkka 1980: 146; 161-163). Muidugi on neil kahel muinasjutul (AT 451 A ja AT 533) üht-teist ühist. Kõige olulisemaks siduvaks elemendiks võib pidada rollivahetuse motiivi, mis pole aga antud juttudele sugugi ainuomane. Erinevusi võib märksa rohkem loetleda. Põhimõttelisemad oleksid järgmised: 1) AT 451 A peategelane on oma vendi otsiv õde, aga mitte oma kihlatu juurde reisiv kuningatütar, nagu AT 533-s; 2) peategelase antagonist on naissoost mütoloogiline olevus, mitte teenijatüdruk ega muu sotsiaalselt alamal seisev naisisik. Neist kesksetest erinevustest tuleneb loomulikult rida teisi, nagu ühelt poolt feodaalne ja teiselt talupoeglikum olustik, rollivahetuse 
Kristi Salve

konkreetne käik jne. Muidugi on lahknevusi ka AT 533 ja AT 451 A kõrvalmotiivides. Igal juhul on mõttekas pidada AT 451 A-d iseseisvaks tüübiks. Seda tingib eeskätt läänemeresoome ja balti rahvaste materjal, ka mari variandid (Genetz 1889), kuna mordva ja vene variandid võivad sisaldada mõlemale omaseid tunnuseid (protagonist otsib küll vendi, aga antagonistiks on teenijatüdruk jne). Ei raatsi märkimata jätta huvitavat tõsiasja: üks 451 A-le lähedane vene variant, mis on kirja pandud Pomorjest (Razumova \& Senkina 1974: 59), st läänemeresoomlaste naabrusest, meenutab mõne detaili poolest läänemeresoome redaktsiooni, samas kui Smolenski kandist pärinev sarnaneb balti tekstidele.

Olles läänemeresoome-balti areaalis üsna ühtlane (st omades kõigilt rahvastelt - karjalastest ja vepslastest alates ning leedulastega lõpetades - fikseeritud variantides piisavalt invariantseid jooni), pakub AT 451 A ühtlasi ilmekaid näiteid rahvuslikest redaktsioonidest ja alaredaktsioonidest.

Toome näiteks mõned kõigile läänemeresoomlastele omastest erijoontest, mis eristavad neid baltipärastest: 1) õde sünnib vendade kodunt ära olles, antagonist vahetab märgid, millega vendadele pidi teatavaks tehtama vastsündinu sugu (nagu öeldud, esineb selline algus samadel rahvastel ka AT 451-s); 2) läänemeresoomlastel siirdub õde jalgsi vendi otsima, kuna balti rahvastel ta kas ratsutab või sõidab vankriga. On tähelepandav, et selles suhtes lähenevad läti ja leedu AT 451 A AT 533-le.

Mõnede teiste motiivide alusel võib rahvuslike redaktsioonide vahel eristada mitmesuguseid seoseid. Nii näiteks ei tunne kõigist läänemeresoome rahvastest ainult eestlased selles muinasjutus hoiatajalooma, kes samal ajal esineb ometi enamikus läti ja leedu variantides. Sealjuures on soomlastel, karjalastel ja vepslastel hoiatajaloomaks eranditult koer, aga lätlastel ja leedulastel võib ette tulla muidki loomi (kass, jänes). Koer on eesti variantideski küll obligatoorne 
tegelane, kuid esineb teises - nimelt veolooma - rollis. Tema kanda ja kaitsta on kingitused vendadele, milleks on riietusesemed, tavaliselt särgid. Ka selles, kuidas õde leiab tee vendade juurde, on lahendused rahvati erinevad. Läänemeresoomlastel on teenäitajaks veerev kuklike, leedulastel annavad vendade asukohast märku nende hobused, kes on õe hobuse varsad ja hirnuvad sellepärast talle vastu.

Läänemeresoomlaste redaktsioon, millest eraldub veel eesti alaredaktsioon, on väga stabiilne. Leedu redaktsioonis võib juhuslikke elemente ette tulla mõnevõrra rohkem. Etnilise ajaloo seisukohalt on ilmselt kõnekaimad läti variandid. Tähelepanu äratab juba levikupilt. AT 451 A läti variandid pärinevad kas maa lõunapiirkondadest või Latgalest. Vastavalt geograafilisele jaotumusele võib läti teisendid jagada ka sisuliselt kaheks redaktsiooniks. Lõunapoolsed variandid kuuluvad õigupoolest kokku leedu redaktsiooniga, Latgale omad aga ilmutavad silmapaistvat lähedust läänemeresoome redaktsioonile, kuid sisaldavad ka erijooni.

Üldiselt on läti variandid vähem stabiilsed kui leedu ja läänemeresoome omad. Eriti kehtib see Latgale suhtes, nii et igas variandis ei esine tingimata kõik järgnevalt loetletud jooned: 1) Latgale versioonis võivad puududa läänemeresoome redaktsioonile omased, AT 451ga ühised algusmotiivid; 2) Latgales viib õde vendadele kingitusi (riietusesemeid, kuklikesi) palju sagedamini ja tüüpilisemalt kui LõunaLäti ja Leedu redaktsioonis; 3) õe ja antagonisti kujuvahetus toimub vastastikuse näkkusülitamise kaudu (see arhailine motiiv, mis kajastab muistset elundhingekujutelma, on säilinud ainult mõnes üksikus eesti, karjala ja Latgale variandis); 4) mõnes Latgale variandis võime kohata nõiatütre poolt kõrvaletõrjutud õe laulus, millega ta püüab ennast vendadele äratuntavaks teha, värsse, kus palutakse kuklikest veereda üheksa vennani. Niisugused värsid on tüüpiliselt omased eesti alaredaktsioonile, kus nad on ka sisuliselt põhjendatud: õde pöördub niimoodi teekonda alustades otse veerema pandud kuklikese 
Kristi Salve

poole, mis saabki tegelikuks teenäitajaks. Latgales on niisugused värsid irdosaks ja jääksid ilma eesti materjalis pakutava seletuseta mõistatuslikeks. Süžee arengu seisukohalt pole niisugustel värssidel mingit funktsiooni. Erandina on Latgalest kirja pandud ka üks väga lühike tekst, õieti konspekt, milles kuklike tõepoolest teed näitab.

Väärib rõhutamist, et AT $451 \mathrm{~A}$ on olnud tuttav ka lutsi maarahvale ja sealjuures spetsiifiliselt eestilikul kujul. Latgale läti variantide kujunemine on pidanud toimuma kauges minevikus, kunagise läänemeresoomelise elanikkonna baltistumise käigus. Nii seletuvad kõrvuti esinevad läänemeresoome ja balti jooned (ka Latgales sõidab õde hobusega), kuid samuti mõned ilmselt kohaliku eriarengu tulemusena tekkinud sisuelemendid. Viimastest väärib tähelepanu see, et kujuvahetus toimub mõnigi kord saunas. Sellega seoses korduvad episoodid sauna kütmisest ja õe meelitamisest sauna - samuti nagu põhjapoolses läänemeresoome redaktsioonis suplema kutsumised.

Tähelepanu äratab põhja- ja lõunapoolsetest naabritest erinev hoiatajalooma puudumine eesti AT $451 \mathrm{~A}$ variantides ja koera hoopis teistsugune funktsioon. Võib arvata, et tegu on Eestis toimunud muutusega ja et teised rahvad on säilitanud algsema kuju. Tuleb ju hoiatajaloom ette isegi vene AT $451 \mathrm{~A}$-le väga lähedastes juttudes, mis on idaslaavi kataloogis (SUS) paigutatud nr 533 alla. Vaatamata mõnedele tõesti AT 533 poole hoidvatele ja mõnedele ilmselt juhuslikele joontele ilmutavad kolm esimest vene varianti sarnasust läänemeresoome või balti AT 451 A redaktsiooniga.

Mordva variantides esineb mitmeid juhuslikuvõitu ja uuemaid, kuid ka väga arhailisi jooni. Tähelepanu äratab üks mordva ja setu variantides harva kohatav motiiv, mis osutab Kaukaasia-suunalistele kultuurisidemetele (Masing 1985), nimelt langeb pärast vendade kodunt lahkumist sündinud ja üksi kasvanud õde mängukaaslaste pilke alla. Just sedakaudu saab ta üldse teada vendade olemasolust. Siiski on Mordvas antagonistiks orjatüdruk, aga mitte uskumusolend. 
Erinedes küll mõneti läänemeresoome-balti AT 451 A-st, on mordva jutud samal ajal ka tüüpilisest AT 533-st siiski niivõrd kaugel, et Andrei Maskajev pole seda nõrka seost tabanud (Maskajev 1967: 260-272, 375).

Mari vastavaid jutte (Genetz 1889: 5, 12) võib kõhkluseta pidada AT 451 A-ks. Antagonistiks on maridelgi mütoloogiline olend, näiteks veevaimu tütar.

\section{Teine lähivaade: tuline auk ja hingelind}

Mitmes mõttes AT 451 A-le lähedane on AT 452 C* (Sõsar käoks). Sedagi muinasjututüüpi on esimesena kirjeldanud J. Balys leedu materjali põhjal. AT $452 \mathrm{C}^{*}$ on osutunud leedu-eesti ühiseks tüübiks juba enne leedu kataloogi ilmumist: esimese eesti variandi on avaldanud Oskar Kallas 20. sajandi algul (Kallas 1900). Hiljem on variante lisandunud hulgi, kuid peaaegu ainult lutsi maarahvalt ja setudelt. Jutu puudumine soomlastel, karjalastel ja lätlastel on üsna kindel, arvestades nende ainestiku läbitöötatuse taset. Siinkohal tasub meenutada, et ka AT $530 \mathrm{~B}^{*}$ oli neil rahvastel väga hapra traditsiooniga. Põhjus võib olla küll mõlemal puhul varem tuntud jutu vähem või rohkem täielikus unustamises. Samavõrd võiks eeldada ka AT $452 \mathrm{C}^{*}$ kunagist laiemat tuntust Eesti alal - ja nagu üks juhuleid osutab, on see eeldus ilmselt paikapidav: Räpina kihelkonna (tõsi, Setumaa vahetus naabruses) rahvaluulekirjapanekute hulgas paikneb AT $452 \mathrm{C}^{* *}$ teisend (H II 52, 470/5 (31)).

Jututüübi kõrget iga tunnistab tema esinemine eestlastel ja leedulastel, kusjuures redaktsioonide omavahelised erinevused on üsna suured. Huvitav lahknevus on see, et Eesti variantides esineb hoiatajaloom, kes Leedus puudub. Seega on olukord vastupidine AT $451 \mathrm{~A}-\mathrm{s}$ kohatavaga, ja kindlasti mitte juhuslikult. Võib oletada, et teadlikult välditi sarnast motiivi lähedastes juttudes. On ju ka AT $452 \mathrm{C}^{*} \mathrm{pu}-$ hul tegu eemalolevate vendadega, samuti mütoloogilise naisolendi 
Kristi Salve

tungimisega õe ja vendade vahele. Erinevalt Üheksa velje sõsarast ei lahku õde AT452 $C^{*}$-s kodunt ja sellepärast ongi eesti variantide hoiatajaloomaks kass, kes sobib tubasesse olustikku paremini.

AT $452 \mathrm{C}^{*}$ setu ja lutsi variantides võtab halva ehk vanahalva (arhailine, inimese suhtes üldiselt pahatahtlik uskumusolend) tütar vendade õena esinemiseks enda peale tema varju. Siin puutume taas kokku arhailiste hingekujutelmadega, uskumisega hinge (või elujõu) ja inimese välisilme tihedasse seosesse (vt nt jumi ja puna regilauludes).

Huvitavaks paralleeliks AT 451 A ja AT $452 C^{* *}$ läänemeresoomelistes redaktsioonides esinevale kujuvahetusele võib tuua ühe arktilise kultuuripiirkonna jutu, milles samuti on kesksel kohal rollivahetus, kuigi jutt ise läheneb rohkem ATU 403 C-le (Rõugutaja tütar). Selles eskimo muinasjutus (Rubtsova 1954: 38) hõõrub rollianastaja enda nägu vastu mehe õige naise oma ja muutub selle tagajärjel temanäoliseks. Rollianastaja pole inimene, vaid mardikas.

Muinasjutul ATU $403 \mathrm{C}$ on aga mitmeid muidki huvitavaid seoseid praegu vaadeldava jutuga. Muinasjutt on levinud mitmetel läänemeresoome rahvastel, aga ka lätlastelt ja leedulastelt on mõned variandid fikseeritud. Sageli, eriti Karjalas ja Kagu-Eestis, esineb ta stabiilsetes kontaminatsioonides, mis on üks traditsiooni tugevuse ilminguid. Selleski jutus esinevad antagonistidena vanapärased mütoloogilised olendid, näiteks Syöjätär Karjalas, vanahalvad Setumaal, Äiatar Võrumaal jne. Situatsioon, kus mehel on kaks naist, inimnaine ja mitteinimene (loom või mütoloogiline olend), esineb ka nganassaani muinasjuttudes (Dolgihh 1976: nr 15) ja tähelepanuväärselt sarnasena läänemeresoome ATU $403 \mathrm{C}$-le saab mees kurivaimust lahti, hukates ta tulises augus. Etioloogiline lõpp, mille järgi põletatud halvast olendist tekivad mitmesugused muud vastumeelsed elukad, on tuntud läänemeresoome ATU 403 C variantides ja õige laialt Siberis (ka näiteks eespool kõne all olnud jutus AT 975* 
(Vahetatud lapsed)). Siberis on kõige tavalisemad tekkima seal inimeste elu eriti kibedaks tegevad sääsed, kuid nii Siberis kui läänemeresoomlastel võib põlenud paha olend muutuda ka muudeks putukateks-satikateks või röövlindudeks.

Tuline auk on hukkamisviisiks ka AT $452 \mathrm{C}^{*}$-s, kuid et seal on hukutatu positiivne inimtegelane, lendab august välja hoopis hingelinnuna tuntud kägu. Igatahes on kõik kolm viimati vaadeldud juttu otse või kaudselt seotud ning vahendavad ühtmoodi arhailist maailmapilti. Ka karjala runos Lemminkäisen virsi kirjeldatakse tulist auku kui kangelast teel ähvardavat surmaohtu. Näeme, et antud puhul on motiiv leidnud kasutamist juba teises žanris. Veel kõnekam tõend tulise augu motiivi iidsuse kohta on see, et hukkamist tulises augus kirjeldab kitšee maiade eepos (Popol Vuh 1999: 88). Kui tulla tagasi setude koduse Pihkva järve äärde, siis sealt pärit vürstinna Olga põletas Kiievis kättemaksuks oma mehe vürst Igori eest tulises augus drevljaanide hõimu ülikud (Aleksandrov 1995). Hukatavad olevat sealjuures paati(desse) asetatud - kajastus skandinaaviapärasest paatmatusest. Seega on tegemist globaalse levikuga motiiviga ning polegi esmatähtis, kas see on ajalooline või folkloorne.

Läänemeresoome-balti juttude hulka võib arvatavasti lugeda ka setudel ja leedulastel tuntud jutud, mida saab vaadelda ühe tüübi kahe tugevasti erineva redaktsioonina. Selle eesti materjalil rakenduva tüübinimetusena on olnud kasutusel Söepuder, leedulastel aga Tütarlaps Aguonele (muinasjutukataloogides pole seda juttu kirjeldatud, seetõttu puudub ka tüübinumber). Muidugi võib, arvestades leedu ja setu juttude olulisi erinevusi, väita, et tegemist on pigem paralleeltüüpidega. Viimasest vaatekohast lähtuvalt on Söeputru peetud puhtsetu muinasjutuks (Masing 1984). Leedu jutu nimikangelane on must juba sündimisest saadik, kuna eesti jutus muutub õde mustaks söepudru söömise tagajärjel, mida nad vennaga kahekesi kodu hoidmas olles "eraks" on keetnud, või jälle söe- ja tuhapudru 
Kristi Salve

kaela kallamisest. Mõlema rahva juttudes viiakse õde merre ligunema, et ta saaks valgeks ja ilusaks. Meres liguneva õe viib minema venna laulu imiteeriv antagonist. Leedus on selleks hunt, Setumaal aga arhailist tüüpi mütoloogiline olend - vanahalv või tikõveline. Tõsi, ühes setu teisendis (S 3003/7 (11)) meelitab sõsara leost välja samuti susi, kuid sööb ta samas ka ära. On ilmne, et tegemist on jututüübi ATU 123 (Hunt ja kitsetalled) mõjuga, millega on nagunii ühine laulmise imiteerimine. Setus läheb vend tavaliselt vanahalva koju, teeskleb surnut ja vanahalvast saadakse lahti (ta tapetakse või sunnitakse põgenema) matuste ettevalmistamise käigus. Leedu redaktsioonis mängitakse muinasjutu lõppvaatus maha Aguonele kodus. Näiliseks surijaks on tütarlapse ema, keda hunt koos Aguonelega tuleb ära saatma. Vend puudub tegelaste seas hoopiski. Tähelepanuväärne on, et hunt hukatakse selles jutus samuti tulises augus.

Läänemeresoome-balti muinasjuttudele nähtavasti üldiselt omaseid jooni, nagu rahvuslike redaktsioonide olemasolu, motiivide katkendlik levik, läti traditsiooni liitumine naaberalade (lõunas leedu, põhjas eesti) omaga jne, võib täheldada ka ATU 150 A (Konna õpetused) puhul. Seda loomamuinasjuttu on, nagu öeldud, uurinud P. Kippar (Kippar 1975). Selgub, et soomlastel, leedulastel ja üldiselt eestlastelgi on tegemist päris loomamuinasjutuga, st fiktsiooniga. Läti traditsioonis on ATU 150 A-d kõneldud tõsiselt võetava tekkeloona, kuna liivlased on seda kasutanud imemuinasjutu sissejuhatuseks. Õpetuste seas on ka juhuslikke, aga paljud neist on siiski traditsioonilised, võides esineda ühtlasi Soomes, Põhja-Eestis ja Leedus. Lõuna-Eesti ja Läti moodustavad õpetuste alusel omaette traditsioonipiirkonna: konn annab seal nõu niine võtmiseks ja viiskude valmistamiseks. Kõik läti variandid on pärit suhteliselt kitsalt alalt maa põhjaosas. Lõuna-Eesti ja Põhja-Läti traditsioonide lähedust on märgata mitte ainult rea muinasjuttude põhjal, vaid ka muudes liikides, 
nt rahvalauludes, kalendritähtpäevadega soetud uskumustes ja kommetes (Tampere 1977: 135).

\section{Vahekokkuvõtteks ja lõpetuseks}

Rea läänemeresoome-balti imemuinasjuttude arhailisele sisule ja eriti olulistel usundilistel kujutelmadel põhinevatele episoodidele on eespool korduvalt osutatud. Aga usundiline aspekt pole ainus, milles väljendub nende muinasjuttude vanapärasus. Arhailisus ilmneb ka miljöökujutuses ning tegelaste ja nende suhete iseloomustuses. Vormitasandil võib täheldada laululiste vaheosade keskmisest sagedasemat esinemist läänemeresoome-balti juttude rühmas (Salve \& Sarv 1987: 19-20). Sünkretismiilminguna väljendavad muinasjuttude laululised vaheosad kaugele minevikule omast kunstilist mõtlemist.

Kui püüda kokkuvõtlikult esitada läänemeresoome-balti muinasjuttude geograafilise leviku põhilisi tendentse, tuleb kahtlemata esile tõsta areaali idaosa kaalukust. Idapoolne levik domineerib eriti imemuinasjuttude osas, kuna legendilaadsed ja loomamuinasjutud paigutuvad ühtlasemalt. Kui vaadelda eesti repertuaari levikupildi seisukohalt, torkab silma läänemeresoome-balti muinasjututüüpide väga tugev esindatus setude asualal. Ainult mõnel neist juttudest (nt ATU 832, AT 240 ja AT 240*) puuduvad setu variandid. Hoopis sagedasem on olukord, kui eesti variandid pärinevad kõik setudelt või ka setudelt ja lutsi maarahvalt (ATU 156 B*, AT $452 \mathrm{C}^{*}$,

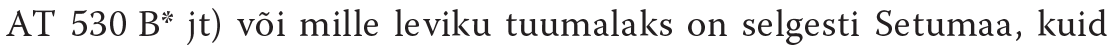
mida on hästi tundnud ka lutsi maarahvas ja millest on üksikuid variante mujaltki Lõuna-Eestist. Üks selliseid on AT 451 A, millest Jakob Hurda kogus on üks Kambja variant. Ülejäänud arhiivimaterjal on Setu või Lutsi päritolu. Jutu kunagist laiemat tuntust lubab Kambja variandile lisaks lisaks (seda võiks ju, kui tahta jutu tuntust väljaspool Setu-Lutsi ala eitada, pidada setu eeljutustajalt kuulduks) oletada ka tema esinemine Juhan Kunderi muinasjutu- 
Kristi Salve

väljaandes (Kunder 1885). Enamasti on J. Kunder kasutanud oma kodukandi ainestikku, pealegi esineb tema tekstis setu variantides tundmatu kontaminatsioon (AT 451 A + AT 511). Jutu kunagist tuntust Viljandimaal kinnitab ka üks Helme regilaulutekst (ERIA III 2, 766), kus liitena esinevad värsid, millega AT 451 A eesti variantides õde koera poole pöördub.

AT 451 A, samuti eespool vaadeldud AT $452 C^{*}$ näide lubavad kindlamad olla selles, et muudki jutud, mille levila on hiljem ahenenud Setumaani (ja lutsi maarahvani), on olnud kunagi tuntud laiemalt. Kas päris kõik ja kas üle kogu maa, see küsimus on juba raskemini vastatav. Alates ulatusliku rahvaluulekogumise algusest, seega 19. sajandi viimasest kolmandikust, on Lõuna- ja Ida-Eesti olnud muinasjuturikkamad kui Põhja- ja Lääne-Eesti. (Loode-Eesti on olnud ühtlaselt vaene kõigi rahvaluuleliikide osas.) Kõige muinasjuturikkam on A. Aarne kataloogi materjali põhjal olnud Võrumaa. Hiljem on eriti kasvanud Setumaa osa niisugustes kogudes nagu ERA, S ja RKM sisalduva materjali arvel. Veel suurem on setu materjali osa helisalvestistes. See pärineb aegadest, mil muinasjuttude kogumine oligi tõeliselt tagajärjekas ainult Setu alal. Küsimus ei taandu aga ainult - ja isegi mitte põhiliselt - kvantiteedile, vaid arvesse tuleb selline tegur nagu Lõuna-Eesti folkloorne unikaalsus (Krikmann 2003). Sellel võib omakorda olla mitmesuguseid põhjusi, mida aga siinkohal pole mõtet eritlema hakata, sest olemasoleva hilise materjali põhjal on midagi kindlamat väita riskantne. Paljud probleemid jäävad paratamatult lahenduseta - näiteks kas või nn lõunaeestiliste juttude kunagine võimalik tundmine ka Põhja-Eestis.

Käesolevas artiklis pole võetud eesmärgiks siduda teatud muinasjutukihistusi kindlate arheoloogiliste kultuuride või keelenähtuste levikuga, samuti pole üritatud anda mingeid dateeringuid. Vastavad otsustused oleksid paratamatult spekulatiivsed, seda nii se- 
nise uurimistöö piisamatuse tõttu, kuid veelgi olulisemalt seetõttu, et eesti muinasjutud on talletatud ajal, kui traditsioon oli hääbumisjärgus.

Kui arvestada kataloogide olemasolu ja arhiivide korraldatuse taset, on suhteliselt head eeldused edaspidiseks viljakaks uurimistööks just läänemeresoome-balti muinasjuturepertuaaride suhete alal. Kahjuks kammitseb järelduste tegemist läänemeresoome (või ka läänemeresoome ja balti rahvaste) muinasjuttude võimalike soomeugriliste vastete puudulik tundmine. Selle objektiivseks põhjusteks on rahvuslike muinasjutukataloogide puudumine, teaduslike väljaannete vähesus ning arhiivi- ja uurimistöö vajakajäämised. Idapoolsete soomeugri, kuid ka uurali ja üldse Siberi põlisrahvaste repertuaaridest piisava ülevaate saamine aitaks määratleda meie muinasjuttude kõige vanemaid kihistusi ja ühtlasi ka mõista, mis balti ja läänemeresoome rahvaste ühistest juttudest juurdub läänemeresoome rahvaste kaugemas minevikus ja mis on tekkinud või läänemeresoomlasteni jõudnud balti rahvastega suhtlemise tulemusel.

Muidugi takistab julgemate järelduste tegemist ka artikli algul kõne all olnud muinasjuttude loomuomane labiilsus. Keraamikakild võib aastatuhandeid muutumatult maapõues lebada, et leidmise korral anda usaldatavat teavet oma ea ja päritolu kohta. Suulise pärimuse teel meieni jõudnud muinasjuttudes on aga, piltlikult öeldes, kõik kultuurikihid lootusetult segamini läinud. Kõige muistsemad ja üsna uued astuvad meie ette kõrvuti või lausa üksteisega läbipõimunute ja kokkukasvanutena, sest uued ja vanad jutud on võinud elada ühe ja sama jutustaja mälus, samuti on muistseid motiive tunginud uuematesse juttudesse ja vastupidi - vanemaid on moderniseeritud.

Nii ongi käesoleva artikli põhiliseks eesmärgiks olnud rea jututüüpide geograafilise leviku ja varieerumise jälgimine, selle alusel nende juttude grupeerimine ja esialgse iseloomustuse visandamine. Loodetavasti suudavad artiklis esitatud empiirilised tähelepanekud 
Kristi Salve

olla mingil määral kasulikud etnilise ajaloo edaspidisel uurimisel. Üks peaks küll juba siin esitatu põhjal olema ilmne: muinasjutud annavad kinnitust läänemeresoome ja balti hõimude ammuaegsetest ja tihedatest kontaktidest. Nende algus võib ulatada ajajärku, kui läänemeresoomlased polnud veel ära lõigatud volgasoome rahvastest ja balti hõimude asualad ulatusid palju kaugemale itta. Intensiivsem suhtlemine toimus juba Läänemeremail. Muinasjuttude põhjal saab jälgida ka etnilisi protsesse praeguse Läti territooriumil, sealjuures eriti Põhja-Lätit varasemal ajal asustanud läänemeresoomlaste keele- ja kultuurivahetust.

\section{Kommentaarid}

${ }^{1}$ Muinasjuttude tüübinumbrid on artiklis üldjuhul antud uusima rahvusvahelise kataloogi järgi. Kui aga selles või teistes uuemates kataloogides on erinevaid jutte kokku liidetud, on viidatud varasematele, mis kajastavad objektiivset olukorda adekvaatsemalt. Ka tüübinimedest on kasutatud eelistatavalt rahvusvahelises käibes olevaid, jättes endale siiski vabaduse kasutada vajadusel vähemtuntud, kuid eesti variantidele sisuliselt sobivamaid või ilmekamaid.

${ }^{2}$ Risto Järve juhendamisel sisestatud muinasjutud on kõik bona fide arvestatud täisväärtuslike variantidena, kuid nagu on näidanud kogemused teiste žanride, eeskätt vanasõnadega, moodustavad märkimisväärse osa materjalist koopiad, kogujapoolsed fantaseeringud jms. Sellepärast olen käesolevaski artiklis vältinud variantide täpse arvu nimetamist.

${ }^{3}$ Hämmastavalt rikas materjal sisaldub Juri Berezkini andmebaasis aadressil http:// www.ruthenia.ru/folklore/berezkin (vt Berezkin), milles on kokkupuuteid mitmete siinses artiklis käsitletud juttudega. J. Berezkin arvestab siiski mütoloogilisi motiive, mistõttu ei ole võimalik neid ühitada muinasjututüpoloogiaga.

\section{Arhiiviallikad}

ERA = Eesti Rahvaluule Arhiivi rahvaluulekogu (1927-1944)

$\mathrm{H}$ = Jakob Hurda rahvaluulekogu (1860-1906)

RKM = Eesti TA Fr. R. Kreutzwaldi nim (Riikliku) Kirjandusmuuseumi (nüüd

Eesti Kirjandusmuuseumi) rahvaluule osakonna rahvaluulekogu (peamiselt alates 1945. aastast)

S = Samuel Sommeri setu vanavarakogu (1922-1936) 


\section{Kirjandus}

AА = Андреев, Николай 1929. Указатель сказочных сюжетов по систеле Аарие. Государсвенное Русское Географическое Общество: Сказочная Комиссия. Ленинград: Издательство Государсвенного Русского Географического Общества.

Aarne, Antti 1911 = Finnische Märchenvarianten: Verzeichnis der bis 1908 gesammelten Aufzeichnungen. Folklore Fellows Communications 5. Hamina: Suomalaisen Tiedeakatemian kustantama.

Aarne, Antti 1918 = Estnische Märchen- und Sagenvarianten: Verzeichnis der zu den Hurt'schen Handschriftssammlungen gehörenden Aufzeichnungen mit der Unterstützung der Finnisch-ugrischen Gesellschaft. Folklore Fellows Communications 25. Hamina: Suomalainen Tiedeakatemia.

AaUs = Ursprungssagen (eesti k tekkemuistendid; vt Aarne 1918)

Aleksandrov, Anatoli 1995. Vürstinna Olga kolmekordne kättemaks. Austrvegr = Idatee: Muinasteaduse ajakiri 1 . Tallinn: Tael, lk 24-28.

Annist, August 1966. Friedrich Reinhold Kreutzwaldi muinasjuttude algupära ja kunstiline laad. Tallinn: Eesti Raamat.

Arājs, Kārlis \& Medne, Alma 1977. Latviešu pasaku tipu rādītājs = Ykaзamesı mипов латыиских народных сказок = The types of the Latvian folktales. Rīgā: Izdevniecība Zinātne.

Ariste, Paul 1981. Keelekontaktid: Eesti keele kontakte teiste keeltega. Eesti NSV Teaduste Akadeemia Emakeele Seltsi toimetised 14. Tallinn: Valgus.

Ariste, Paul 2005. Komi rahvaluulet: Kogunud Paul Ariste I = Kоли фольклор: чукӧртіс П. Аристэ I = Коли фольклор: Собрал П. Аристэ I = Komi folklore: Collected by P. Ariste I. Kuznetsov, Nikolai (koost). Tartu: Eesti Kirjandusmuuseum.

AT = Aarne, Aarne \& Thompson, Stith 1928, 1961, 1973.

AT = Aarne, Aarne \& Thompson, Stith 1928. The Types of the Folktale: A Classification and Bibliography. A. Aarne's Verzeichnis der Märchentypen. Folkore Fellows Communications 74. Helsinki: Suomalainen Tiedeakatemia = The Types of the Folktale: A Classification and Bibliography. A. Aarne's Verzeichnis der Märchentypen (FFCommunications No. 3). 2., täiend tr. Folklore Fellows Communications 184. Helsinki: Suomalainen Tiedeakatemia $1961=$ The types of the folktale: A classification and bibliography. 3. tr. Folkore Fellows Communications 184. Helsinki: Suomalainen Tiedeakatemia 1973. 
Kristi Salve

ATU = Uther, Hans-Jörg 2004. The types of international folktales: A classification and bibliography; based on the system of Antti Aarne and Stith Thompson. Folklore Fellows Communications 133-135: 284-286. Helsinki: Suomalainen tiedeakatemia.

Balys, Jonas 1936. Lietuviu pasakojamosios tautosakos motyvų katalogą = Motifindex of Lithuanian narrative folklore. Tautosakos Darbai: Folk-lore studies: Publication of the Lithuanian folk-lore archives 2. Kaunas.

Berezkin = Березкин, Юрий. Телатическая классификация и распределение фольклорно-лифологических лотивов по ареалал: Аналитический каталов (http://www.ruthenia.ru/folklore/berezkin - 7. juuli 2006).

Dolgihh 1976 = Долгих Борис (toim). Мифологические сказки и исторические предания нганасан. Сказки и мифы народов Востока. Москва: Наука, Главная редакция восточной литературы.

ERIA III = Tedre, Ülo (toim) 1971-1972. Eesti Rahvalaulud: Antoloogia 3:13. Tallinn: Eesti Raamat (http://www.folklore.ee/laulud/erla/ - 16. mail 2006).

Genetz, Arvid 1889. Ost-Tscheremissische Sprachstudien 1: Sprachproben mit deutscher Übersetzung. Suomalais-ugrilaisen seuran aikakauskirja 7. Helsingfors: Dr. der Finnischen Literatur-Gesellschaft.

Hurt, Jakob 1904. Setukeste laulud: Pihkva-Eestlaste vanad rahvalaulud, ühes Räpinä ja Vastseliina lauludega 1. Monumenta Estoniae antiquae I: Carmina popularia 1. Suomalaisen Kirjallisuuden Seuran toimituksia 104. Helsingi: Soome Kirjanduse Selts.

Itkonen, Erkki 1960. Lappalainen haltijatarpari ja sen siperilanen vastine. Kalevalaseuran Vuosikirja 40, lk 134-144.

Itkonen, Erkki 1976. Älteste Elemente der lappischen Volksüberlieferung. Suomalais-Ugrilaisen Seuran Aikakauskirja = Journal de la Société Finno-Ougrienne 74. Helsinki: Suomalais-ugrilainen seura, lk 5-57.

Järv, Risto 2005 Eesti imemuinasjuttude tekstid ja tekstuur: Arhiivikeskne vaatlus. Dissertationes folkloristicae Universitatis Tartuensis 7. Tartu: Tartu Ülikooli Kirjastus.

Kallas, Oskar 1900. Kaheksakümmend Lutsi Maarahva muinasjuttu. Äratrükk: Õpetatud Eesti Seltsi toimetused 20. Jurjev : Schnakenburg.

Kerbelytė, Bronislava 1982. Litauische Volksmärchen. 2., täiend tr. Volksmärchen: Eine internationale Reihe. Berlin: Akademie-Verlag. 
Kippar, Pille 1975. Konna õpetused (AT 150 A*). Muinasjututüübi AT 150 lääne-meresoome-balti redaktsioon. Ahven, Heino (toim). Emakeele Seltsi Aastaraamat 19/20. 1973/1974. Tallinn: Emakeele Selts, lk 263-289.

Kippar, Pille 1984. Vadja muinasjutu viimane aastasada. Ahven, Heino (toim). Keelest ja rahvaluulest. Emakeele Seltsi Aastaraamat 30. Tallinn: Eesti Raamat, lk 136-143.

Kippar, Pille 1985. Varese naisevõtt (AT 243*). Tedre, Ülo et al. (toim). Rahvasuust kirjapanekuni: Uurimusi rahvaluule proosaloomingustja kogumisloost. Emakeele Seltsi Toimetised 17. Tallinn: Eesti NSV Teaduste Akadeemia, lk 83-100.

Kippar, Pille 1986. Estnische Tiermärchen: Typen- und Variantenverzeichnis. Folklore Fellows Communications 237. Helsinki: Suomalainen Tiedeakatemia.

Konkka 1980 = Конкка, Унельма. Духовная культура сегозерских карел кониа XIX - начала XX веков. Клементьев, Евгений (toim). Ленинград: Наука.

Krikmann, Arvo 2003 Lõuna-Eesti folkloori- ja keeleaine unikaalsusest. Tartu Ülikooli Lõuna-Eesti keele-ja kultuuriuuringute keskuse aastaraamat II: 2002. Tartu: Tartu Ülikooli Lõuna-Eesti keele- ja kultuuriuuringute keskus, lk 11-30.

Kunder, Juhan (koost) 1885. Eesti muinasjutud. Eesti Kirjameeste Seltsi toimetused 65. Tartu: Eesti Kirjanduse Selts.

Kuusi Matti (toim) 1963. Suomen kirjallisuus I: Kirjoittamaton kirjallisuus. Helsinki: Suomalaisen Kirjallisuuden Seura \& Otava.

Liungman, Waldemar 1961. Die schwedischen Volksmärchen: Herkunft und Geschichte. Veröffentlichungen des Instituts für Deutsche Volkskunde 20. Berlin: Akademie-Verlag.

Livšits 1979 = Лившиц, Исаак (tõlk ja komment). Сказки и повести, Древнево Ezипта. Литературные памятники. Ленинград: Наука.

Loorits, Oskar 1934. Contributions to the material concerning Baltic-Byzantic cultural relations. Folk-Lore 45: 1, 1k 47-73.

Masing, Uku 1977. Kõuelind ja veesarvik (AaTh 1148 B). Nurmekund, Pent (toim). Studia orientalia et antiqua II. Tartu Riikliku Ülikooli toimetised 416 = Ученые записки Тартуского государственного университета 416 = Acta et commentationes Universitatis Tartuensis. Tartu: Tartu Riiklik Ülikool, lk 117-169.

Masing, Uku 1984. Esten. Ranke, Kurt \& Brednich, Rolf Wilhelm \& Bausinger, Hermann et al. (koost \& toim). Enzyklopädie des Märchens: Handwörterbuch 
Kristi Salve

zur historischen und vergleichenden Erzählforschung 4. Berlin \& New York: Walter de Gruyter, lk 479-491.

Masing, Uku 1985. Mõnedest paralleelidest Kaukaasia ja Eesti folklooris. Tedre, Ülo et al. (toim). Rahvasuust kirjapanekuni: Uurimusi rahvaluule proosaloomingust ja kogumisloost. Emakeele Seltsi Toimetised 17. Tallinn, 101-121.

Masing, Uku 1990. Gottes Segen. Ranke, Kurt \& Brednich, Rolf Wilhelm \& Bausinger, Hermann et al. (koost \& toim). Enzyklopädie des Märchens: Handwörterbuch zur historischen und vergleichenden Erzählforschung 6. Berlin \& New York: Walter de Gruyter, lk 12-16.

Maskajev 1967 = Маскаев, Андрей (koost). Эрзянские сказки 3: 2. Саранск: Мордовское книжное издат.

Medne, Alma 1940. Latviešu dzīvnieku pasakas = Review of New Types in the MotifIndex of Latvian Animal Tales. Latviešu folkloras krātuves materiali. Rīgā 1940.

Popol Vuh 1999 = Popol Vuh: Kitšee maiade raamat. Lias, Ruth (tõlk). Tartu: Ilmamaa.

Razumova \& Senkina 1974 = Разумова, Алуксандра \& Сенькина, Татьяна (koost). Русские народные сказки Карельского Полорья. Петрозаводск: Карелия.

Rausmaa, Pirkko-Liisa 1967. Syöjätär ja yhdeksän veljen sisar: Satu AT 533 ja siihen liittyvä laulu. Suomi 112: 2. Helsinki: Suomalaisen Kirjallisuuden Seura.

Rausmaa, Pirkko-Liisa (koost \& toim) 1972. Suomalaiset kansansadut 1: Ihmesadut. Suomalaisen Kirjallisuuden Seuran toimituksia 302. Helsinki: Suomalaisen Kirjallisuuden Seura.

Rausmaa, Pirkko-Liisa 1973. Läntinen ja itäinen satuperinne Suomessa. Sihvo, Hannes (toim). Karjala: idän ja lännen silta. Kalevalaseuran vuosikirja 53. Porvoo \& Helsinki: WSOY, lk 121-136.

Rausmaa, Pirkko-Liisa (koost \& toim) 1982. Suomalaiset kansansadut 2: Legendaja novellisadut. Suomalaisen Kirjallisuuden Seuran toimituksia 377. Helsinki: Suomalaisen Kirjallisuuden Seura.

Rubtsova 1954 = Рубцова, Екатерина. Материаль по языку и фольклору эскилосов 1. Москва \& Ленинград: Изд-во АН СССР.

Rüütel, Ingrid 1969. Eesti uиema rahvalaulu kujunemine. Dissertatsioon filoloogiakandidaadi teadusliku kraadi taotlemiseks. Tartu. Käsikiri Eesti Rahvaluule Arhiivis,

Salve 1984 = Сальве, Кристи. Скрытая Сестра девяти братьев : (О распространении и трактовке АТ 451 А и АТ $452 \mathrm{C}^{*}$ ). Исторические и культурные 
сьязи балтов и прибалтийских финнов. Тезисы докладов республиканской научной конферениии 22-23 ноября 1984 „. Вильнюс: Вильнюсский государственный педагогический институт, lk 30-33.

Salve, Kristi 1992. Lorijal lõuvad, kuuljal kõrvad (Ida-Virumaa rahvajuttudest). Rüütel, Ingrid (toim). Ida-Virumaa rahvakultuurist. Tallinn: Infotrükk, lk 82-100.

Salve, Kristi 1995. Kangelaslugu Siberist läänemeresoomlasteni. Blomstedt, Jan \& Lõhmus, Maarja \& Tarasti, Eero (toim). Ajalaval: Kangelane Eväärtused. Tartu \& Helsinki, lk 112-127.

Sarv, Vaike \& Salve, Kristi 1987. Setu lauludega muinasjutud. Ars musicae popularis 5. Tallinn: Eesti Raamat.

SUS = CУC 1979 = Бараг, Лев \& Березовский, Иван \& Кабашников, Константин \& Новиков, Николай (koost). Сравнтельный указатель сюжеmо6: Восточнославянская сказка. Ленинград: Наука.

Tampere, Herbert 1977. Mõned mõtted liivi rahvalaulust. Rüütel, Ingrid (koost \& toim). Soome-ugri rahvaste muиsikapärandist = музикальне наследие финно-угорских народов. Tallinn: Eesti Raamat, lk 135-148.

Tšistov, Kirill 1958 = Чистов, Кирилл. Былина Рахта Рагнозерский $\quad$ и предание о Рахкое из Рагнозера. Славянская филоловия = Philologie slave: Сборник статей. Москва: Изд-во АН СССР, $1 \mathrm{k}$ 358-388.

Vereštšagin 1995 = Верещагин, Григорий. Собрание сочинений I: Вотяки Сосновского края. Памятники культуры. Ижевск: Российская академия наук, Уральское отделение, Удмуртский институт истории, языка и литературы.

Viidalepp, Richard 1959. Rahvajutud. Viidalepp, Richard (toim). Eesti rahvaluule ülevaade. Tallinn: Eesti Riiklik Kirjastus, lk 353-446.

Viidalepp 1980 = Вийдалепп, Рихард et al. (toim). Эстонский фольклор. Таллин: Ээсти Раамат.

Viidalepp, Richard \& Mälk, Vaina \& Sarv, Ingrid 1967. Eesti muinasjutud: Antoloogia. Tallinn: Eesti Raamat. 


\section{VÕIM \& KULTUUR 2}

\section{Koostaja ja toimetaja Mare Kõiva}

http://www.folklore.ee/pubte/eraamat/voimjakultuur2/

Koostaja ja toimetaja: Mare Kõiva

Keeletoimetaja: Mare Kalda

Inglise keele toimetaja: Tiina Kirss

Makett ja kaas: Alo Paistik

Pilditöötlus: Andres Kuperjanov

HTML: Diana Kahre

ISBN 978-9949-586-83-7 (pdf)

ISBN 978-9949-418-53-4 (trükis)

DOI: $10.7592 / \mathrm{VK} 2.2006$

Tartu 2018

Trükis ilmunud: Võim \& kultuur 2. Koostaja ja toimetaja

Mare Kõiva. Võim ja kultuur. Tartu 2006

E-raamatu valmimist toetas: EKKM14-344 Eesti keele, kultuuri ja folkloori kasutusalade laiendamine ja tutvustamine elektroonilistel infokandjatel.
(C) 2018 Eesti Kirjandusmuuseum
(C) 2018 Eesti Folkloori Instituut
(c) 2018 EKM FO rahvausundi ja meedia töörühm
(C) 2018 autorid 